\title{
Importance about knowledge about human papillomavirus (HPV) and forms of contamination for the prevention of cervical cancer: a literature review
}

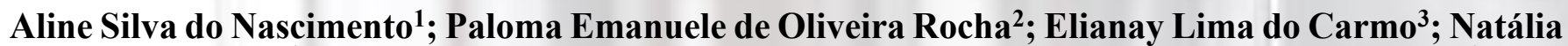 \\ Barbosa Pimentel $^{4}$; Tamires Eduarda Ferreira Salvino5; Sidrielly Cecília Clarice de Assunção6 ${ }^{5}$ Igor \\ Gustavo Alves das Neves ${ }^{7}$; Maria Clara Bezerra Gabu ${ }^{8}$; Fábio Abel de Carvalho9; Luzia Virgínia da \\ Silva ${ }^{10}$; Rayane Vitória Rodrigues Chagas ${ }^{11}$; Adeilda da Silva Alves ${ }^{12}$; Maysa Lohanna Barbosa \\ Santos $^{13}$; Maria Lucikelly Beatriz de Andrade ${ }^{14}$; Anayres Silva de Lima ${ }^{15}$, Allyson Rodrigo de \\ Oliveira Lopes *16 \\ 1 Undergraduate of the bachelor's degree in Pharmacy course at the Academic Center of Vitória de Santo Antão - UNIVISA. \\ 2 Undergraduate of the bachelor's degree in Nursing at the Academic Center of Vitória de Santo Antão - UNIVISA. \\ 3 Undergraduate of the bachelor's degree in Nursing at the Academic Center of Vitória de Santo Antão - UNIVISA. \\ 4 Undergraduate of the bachelor's degree in Pharmacy at the Academic Center of Vitória de Santo Antão - UNIVISA. \\ 5 Undergraduate of the bachelor's degree in Biomedicine at the Academic Center of Vitória de Santo Antão - UNIVISA. \\ 6 Undergraduate of the bachelor's degree in Nursing at the Academic Center of Vitória de Santo Antão - UNIVISA. \\ 7 Graduated of the bachelor's degree in Pharmacy from the Academic Center of Vitória de Santo Antão - UNIVISA. \\ 8 Undergraduate of the bachelor's degree in Pharmacy at the Academic Center of Vitória de Santo Antão - UNIVISA. \\ 9 - 14 Undergraduate of the Course in Biology of the Academic Center of Vitória de Santo Antão - UNIVISA. \\ 15 Nurse at the Federal University of Pernambuco. \\ 16 Professor of the Biomedicine course at the University Center of Vitória de Santo Antão - UNIVISA
}

E-mail adresses: alinenascimentolab@gmail.com (Aline Silva do Nascimento), paloma.201919004@univisa.edu.br (Paloma Emanuele de Oliveira Rocha), elianay.201920006@univisa.edu.br (Elianay Lima do Carmo), natalia.201928411@univisa.edu.br (Natália Barbosa Pimentel) ferreirasalvino@outlook.com (Tamires Eduarda Ferreira Salvino), sidriellyassuncao@gmail.com (Sidrielly Cecília Clarice de Assunção) igorgalves98@gmail.com (Igor Gustavo Alves das Neves), clara.gabu91@gmail.com (Maria Clara Bezerra Gabu), fbabel0@gmail.com (Fábio Abel de Carvalho), luziavieginia1245@gmail.com (Luzia Virgínia da Silva), rayane.vit.rodrigues@gmail.com (Rayane Vitória Rodrigues Chagas), adeilda194@gmail.com (Adeilda da Silva Alves), maysalsantos@gmail.com (Maysa Loanna Barbosa Santos), lucikellybeatriz@gmail.com (Maria Lucikelly Beatriz de Andrade), anayreslima@hotmail.com, (Anayres Silva de Lima), allysonlopes85@gmail.com (Allyson Rodrigo de Oliveira Lopes).

${ }^{*}$ Corresponding author

To cite this article:

Nascimento, A. S.; Rocha, P.E.O.; Carmo, E.L.; Pimentel, N.B.; Salvino, T.E.F.; Assunção, S.C.C.; Neves, I.G.A.; Gabu, N.C.B.; Vravalho, F.A.; Silva, L.V.; Chagas, R.V.R.; Alves, A.S.; Santos, M.L.B.; Andrade, M.L.B.; Lima, A.S; Lopes, A.R.O. Importance about knowledge about human papilloma virus (HPV) and forms of contamination for the prevention of cervical cancer: a literature review. International Journal of Sciences. Vol. 2, No. 1, 2021, pp. 06-09. ISSN 2763-5392

Received: 06 29, 2021; Accepted: 06 30, 2021; Published: 07 15, 2021

\begin{abstract}
The human papilloma virus (HPV) is a more frequent Sexually Transmitted Infection (STIs). It is a type of virus that infects from unprotected sexual intercourse, and can cause cervical lesions and genital warts. The objective of this study was to describe the pathology (HPV) and emphasize the importance of knowledge of the disease Due to few studies emphasizing the problem, the high number of new cases in the population is notorious. This work is a bibliographical research of the narrative type, elaborated from articles published in the databases. The results pointed to the need for preventive intervention, with a greater focus on educational actions, such as raising awareness of the importance of conducting the colpo-cytological examination and treating the LPCC. It is also worth mentioning the low perception of vulnerability among women, allowing greater susceptibility to STD and HPV.
\end{abstract}

Keywords: HPV; STIs; Prevention. 
2 Nascimento, A. S.; Rocha, P.E.O.; Carmo, E.L.; Pimentel, N.B.; Salvino, T.E.F.; Assunção, S.C.C.; Neves, I.G.A.; Gabu, N.C.B.; Vravalho, F.A.; Silva, L.V.; Chagas, R.V.R.; Alves, A.S.; Santos, M.L.B.; Andrade, M.L.B.; Lima, A.S; Lopes, A.R.O. Importance about knowledge..

\section{Introduction}

The human papilloma virus (HPV) is a Sexually Transmissible Infection (STIs). Infect from unprotected sexual intercourse, which can cause lesions of the uterus Colo and genital warts (INCA, 2018).

Infection with this virus is very frequent, but transient, spontaneously regressed most of the time. In the smallest number of cases in which the infection persists is caused by a viral type with potential to cause cancer (oncogenic), triggering precursor lesions that if not identified and treated can progress to cancer, mainly in the colon the uterus, but also in the vulva, anus, penis, oropharynx and mouth, estimate the existence of more than 150 different types of $\mathrm{HPV}$, and about 40 types can infect the genital tract year-tomouth (INCA, 2018).

It is estimated that $25 \%$ to $50 \%$ of the world's female population may be infected with HPV. However, most infections are transient, spontaneously regressing through the immune system and regressing between six months to two years after exposure, especially among younger women. Of the 40 types of papillomavirus that infect the year-genital tract, at least 13 types are considered oncogenic and are likely to cause persistent infections associated with precursor lesions (BRASIL, 2010).

According to the Oswaldo Cruz Foundation, through its Fernandes Figueira National Institute (IFF/FIOCRUZ), HPV is a virus commonly contracted through sexual intercourse. It is estimated that $80 \%$ of people may be infected with it during life, since cases usually appear early in their sex life. It is often found in the male and female genital region and the infection is usually asymptomatic. The visible manifestation in the form of genital wart can cause some discomfort, but internal lesions in the vagina and cervix are completely asymptomatic. Therefore, it is essential for women to perform preventive examination to screen for precursor lesions (CARVALHO, 2009).

In Brazil, about 15,000 cases of cervical cancer have been reported each year, recording a number of 5,000 deaths and 5,000 vaccinations against the virus. The HPV virus is potentially contagious, and it is possible to become contaminated with a single exposure and its transmission occurs by direct contact with the infected skin or mucosa. However, the main form of transmission of the disease is by sexual contact (BRASIL,2013).

HPV infection is difficult to prevent because it depends on direct contact of the injured region with another person's healthy skin, without relying on ejaculation. Thus, condoms should be used as a form of prevention during all forms of sexual intercourse. Another form of prevention would be to have a small number of sexual partners. The prevention of cervical cancer should be done through gynecological examination (MACÁRIO, 2012).

Vaccines against the most common types of HPV that contaminate the genital region are recently available. There are two products: with the two types most commonly related to cervical cancer and another commonly related to genital warts, with two more types of HPV. It is estimated that women who took one of these vaccines before becoming infected with HPV have a reduction of up to $70 \%$ in the likelihood of developing cervical cancer. But, as still remains some risk, even vaccinated women should keep the preventive examination in gynecological consultation (ROSA, 2009).

Prophylactic HPV vaccines were developed around 1993 in developed countries such as England, Australia, the Netherlands and Spain, thus aiming to reduce infection and incidence of cervical cancer. Brazil, following other countries, approved the commercialization of two prophylactic vaccines against HPV, the quadrivalent Merck Sharp \& Dohme (2009) and the bivalent GlaxoSmithKline (2009). Subsequently, in order to achieve a greater volume of immunizations, in 2014, the Unified Health System (SUS) launched a national campaign to immunize girls from 11 to 13 years of age against HPV, free of charge throughout the national territory (BRASIL, 2013).

The best way to prevent HPV infection in the female population is by vaccination. The protection rate of the vaccine against cervical cancer is higher than 93\%. The vaccine does not protect people already infected with the virus. Therefore, the ideal time to receive it is before the beginning of the sex life. With this, the Ministry of Health proposes that awareness and prevention of the disease be initiated at school, soon after the release of free vaccines that are given by the SUS. In this sense, several schools in the country have been conducting campaigns against HPV since then (AGOSTINHO, 2009).

The objective of this study was to describe the pathology (HPV) and emphasize the importance of knowledge of the disease Due to few studies emphasizing the problem, the high number of new cases in the population is notorious.

\section{Methodology}

This work is a bibliographical research of the narrative type, elaborated from articles published in the databases Scielo, LILACS and VHL. Using descriptors: HPV; STIs; prevention. The following were included in the research: books, articles with full text available, published between 2009 and 2019, in Portuguese. They've been excluded...

\begin{tabular}{l|c|c|c|c}
\hline \multicolumn{1}{l}{ Table 1. Found studies } \\
\hline Database & Found & Pre-selected & Deleted & Included \\
\hline SCIELO & 12 & 08 & 03 & 05 \\
\hline LILACS & 10 & 05 & 03 & 02 \\
\hline VHL & 15 & 07 & 05 & 02 \\
\hline total & $\mathbf{3 7}$ & $\mathbf{2 0}$ & $\mathbf{1 2}$ & $\mathbf{0 9}$ \\
\hline
\end{tabular}

Source: Author

\section{Results}


Cervical cancer has its control based on microscopic analysis of changes in the cervical smear, through the Pap smear, which allows early detection of precursor lesions in the affected cells or the cancer itself. However, with the large number of deaths attributed to cervical cancer every year around the world it is assumed that many women still do not perform prevention properly. Thus, following the already used approach for other infectious diseases, which demonstrate immunization as the most effective and cost-effective way of controlling for a disease, HPV vaccines, associated with cervical cancer, were also created (BRASIL, 2013).

These days, genital infection with human papillomavirus (HPV) is the most constant sexually transmitted viral disease in the sexually active population, according to the World Health Organization (WHO) the same causes cervical cancer, which is the fourth most common cancer in women, with an estimated 266,000 deaths and 528,000 new cases in 2012. The vast majority (about $85 \%$ ) of global burden occurs in less developed regions, where it is responsible for almost $12 \%$ of all female cancers (MOREIRA, 2015).

Therefore, in view of the intensity achieved by these Sexually Transmitted Diseases (STD), the absence or uselessness of educational programs for the prevention and promotion of sexually transmitted diseases is evidenced, including HPV. One of the biggest obstacles to controlling STDs is, perhaps, the blocking of definitively influencing the change of habits, behavior and sexual attitude of the population, young or adult, by the number of institutional campaigns (ROSA, 2009).

HPV in the papovaviridae family, capable of conducting skin or mucosal lesions, was annunciated as the leading cause of cervical cancer by the World Health Organization (WHO) in 1992. Infection by this virus can occur in three distinct forms: clinical, subclinical and latent. The clinical forms correspond to verrucous lesions (acuminate condylomas), and the clinical examination is capable of making the diagnosis. The subclinical form is often suspected by alterations in cytology, digital cervicography, colposcopy or histopathological outcome of a biopsy. These tests hint at the presence of the virus. The latent form corresponds to the identification of the virus by molecular biology in the absence of morphological alterations (BRASIL, 2013).

HPV can be located in any region of the body, just by having a gateway through micro-abrasions (microtraumas) of the skin or mucosa. The virus has been found not only in the genital region, but also extragenital as eye, mouth, pharynx, airways, anus, rhetor and urethra. The most common clinical HPV spread in the genital region is warts or condylomas acuminate (AUGUSTINHO, 2009).

Subclinical lesions do not manifest any symptomatology, but may progress to cervical cancer if they are not diagnosed and treated previously. Tumor progression, from infection of normal cells by HPV, seems to be conditioned to factors related to the virus and host-related factors (smoking, prolonged use of oral contraceptives, multiparity, immunosuppression) (MOREIRA, 2015).

The purpose of treatment should be removal of visible warts. Recurrences are relatively frequent because, even if the wart (clinical lesions) is eliminated, the virus in the genital area cannot be completely destroyed. To date, no evidence of treatments for latent HPV infection. In most cases, the body itself is in charge of eliminating the virus (MEDEIROS et. al, 2009).

Early diagnosis of HPV infection is a key action to control transmission of the virus. This control can be found with the effective work of health professionals, since all professionals are responsible for health education. The lack of adequate information about HPV favors the development of erroneous conceptions that can interfere in the behavior of HPV carriers and people who are part of their socio-family context (SILVA, 2013).

Most often, these misconceptions are loaded with cultural elements, such as beliefs, myths and taboos, which have great importance for the individual. Cultural values that are not matched with reality can represent a great barrier for professionals who work in health promotion and disease prevention. In view of this problem, it is considered necessary to carry out an investigation on HPV (VIDALE, 2015).

Addressing feelings experienced by patients who undergo treatment for genital lesions. Based on this knowledge, actions for health education can be based on clarifying possible ideas/beliefs without foundation and promoting the awareness of clients about the true context that involves HPV treatment (ROSA, 2009).

It is known that the woman who is undergoing treatment for HPV lesions often does not have a good knowledge about the pathology. The lack of information makes this period of life of the woman quite conflicting and full of feelings that, in most cases, bring harm to the woman and family (CARVALHO, 2009).

The results found in a survey of the Ministry of Health in all Brazilian capitals and in the Federal District were released on 27-04-2019. About 54.6\% of Brazilians between 16 and 25 years are infected with human papillomavirus (HPV). A total of 7,586 users of the Unified Health System (SUS) were interviewed, but only 2,669 underwent tests to detect the presence of the virus. Of the total number of confirmed cases, $38.4 \%$ of people registered one of the most dangerous types of HPV, capable of causing cancer (BRASIL, 2019).

The majority of respondents stated that they were in a stable union: $41.9 \%$ said they were dating and $33.1 \%$ married or living with their partner. The mean age of sexual beginning was 15.3 years for women and 15 years for men, and the date of first pregnancy remained at 17.1. Salvador (71.9\%), Palmas $(61.8 \%)$ and Cuiabá $(61.5 \%)$ were in the capitals with the highest incidence of HPV. With $41.2 \%$, Recife is on topof the tip, as the least infected (BRASIL, 2019).

On the other hand, we had the respondents who claimed not to have steady partners or to be living without partners at this time. These included the groups of single, separated and widowed, with $26.7 \%$ in (women aged 16 to 45 years) and $43.3 \%$ in (women aged 46 to 55 years) (ROSA, 2009).

Given the description of women with LPCCU (precursor lesions of cervical cancer), in the present study there was a predominance in the age group between 26 and 55 years, an increase in the percentage of women aged between 16 to 25 and 26 to 35 , remaining high at 45 years and presenting a peak between 46 and 55 years, with a frequency of $50 \%$ of women 
4 Nascimento, A. S.; Rocha, P.E.O.; Carmo, E.L.; Pimentel, N.B.; Salvino, T.E.F.; Assunção, S.C.C.; Neves, I.G.A.; Gabu, N.C.B.; Vravalho, F.A.; Silva, L.V.; Chagas, R.V.R.; Alves, A.S.; Santos, M.L.B.; Andrade, M.L.B.; Lima, A.S; Lopes, A.R.O. Importance about knowledge...

and having a decline from 56 years. In this context, young women have a great possibility of spontaneous remission of precursor lesions (MEDEIROS, 2009).

The literature indicates that the higher incidence of cervical-uterine cancer affects women aged between 40 and 60 years, not being common in women under 20 years of age. However, $70 \%$ of cases of cervical-uterine cancer would be related to HPV, and the highest prevalence of HPV contamination is in young women between 15 and 25 years old, a period of onset of sexual activity. Corroborating this statement, Martins et al. (2009) show that adolescents who are sexually active have the highest rates of infections, incidents and prevalent (MOREIRA, 2015).

The present study showed us that women predominated regarding the non-use of condoms and that most women do not protect themselves against STDs. Only $33.3 \%$ of the women in the research use condoms in sexual activities. As for the elderly, the study by Souza, Suassuna and Costa (2009) characterized the epidemiological profile of 20 elderly with HIV diagnoses and pointed out that none of the elderly surveyed used condoms before becoming infected, which makes them a group vulnerable to HPV infection and resembles the results of this study (BRASIL, 2013).

\section{Conclusions}

The results pointed to the need for preventive intervention, with a greater focus on educational actions, such as raising awareness of the importance of conducting the colpo-cytological examination and treating the LPCC. It is also worth mentioning the low perception of vulnerability among women, allowing greater susceptibility to STD and HPV.

In this context, it should be taken into account the elaboration of strategic measures in order to encourage preventive attitudes among women, with regard to the use of condoms. It is noticed in this study that low socioeconomic level and low schooling are important factors that contribute to the acquisition of human papillomavirus infection.

\section{References}

[1] Agostinho, M, I, R. Conhecimento dos jovens universitários sobre HPV e cancro do colo do útero, na era da vacina. 2012. Dissertação (Mestrado) - Curso de Oncologia, Universidade do Porto, 2012. Disponível em: https://repositorio-

aberto.up.pt/bitstream/10216/63643/2/Tese\%20MestradoMari sa\%20Agostinho.pdf. Acesso em: 20 de março de 2019.

[2] BRASIL. Ministério da Saúde. Secretaria de Atenção à Saúde. Instituto Nacional de Câncer. Coordenação de Prevenção e Vigilância. Nomenclatura Brasileira para laudos cervicais e condutas preconizadas: recomendações para profissionais de saúde. Instituto Nacional do Câncer; 2019.

[3] BRASIL. Ministério da Saúde, Secretaria de Vigilância em Saúde. Programa Nacional de Imunizações (PNI). Brasília; 2013. Disponível em: http://www.blog.saude.gov.br/index.php/entenda-o-sus/50027programa-nacional-de-imunizacoes-pni. Acesso em: 20 de março de 2019.
[4] BRASIL. Ministério da Saúde. Secretaria de Assistência à Saúde. Instituto Nacional do Câncer. Coordenação de Prevenção e Vigilância. Estimativa 2010: Incidência de Câncer no Brasil. Rio de Janeiro: Instituto Nacional do Câncer; 2010.

[5] BRASIL. Ministério da Saúde. Secretaria de Atenção à Saúde. Departamento de Ações Programáticas Estratégicas. Manual de Atenção à Mulher no Climatério/Menopausa. Brasília: Editora do Ministério da Saúde. Série Direitos Sexuais e Direitos Reprodutivos. 2008.

[6] CARVALHO, J.J.M. Manual prático do HPV: Papilomavírus humano. São Paulo: Instituto Garnet; 2009.

[7] CARVALHO, M.C.M. Representações Sociais de mulheres portadoras de lesões precursoras do câncer cérvico-uterino: um novo olhar pela enfermagem oncológica [Dissertação Mestrado] Rio de Janeiro: Universidade Federal do Rio de Janeiro, 2009.

[8] INCA. INSTITUTO NACIONAL DO CÂNCER. Coordenação de Prevenção Vigilância (Conprev). Falando sobre câncer do colo do útero. Rio de Janeiro: INCA, 2018.

[9] MACÁRIO, D. Campanha do HPV registra baixa adesão. Diário do Grande ABC. Santo André. Disponível em: http://www.dgabc.com.br/Noticia/1316574/campanha-do-hpvregistra-baixaadesao. Acesso em: 20 de março de 2019.

[10] MARTINS, C.M.R, et al. Associação entre idade da atividade sexual e subsequente infecção por papilomavírus humano:resultados de um programa de rastreamento brasileiro. Revista BrasGinecolObstet 2009.

[11] MEDEIROS, V.C.R.D. et al. Câncer de colo de útero: análise epidemiológica e citopatológica no Estado do Rio Grande do Norte. RBAC 2009.

[12] MOREIRA, K. Vacinação contra HPV tem baixa adesão em Porto Alegre. Gaúcha. Porto Alegre. Abr. 2015. Disponível em: /noticiaaberta/iniciada-em-marco-campanha-de-vacinacaocontra-hpv-tem-baixaadesao-em-porto-alegre-135251.html. Acesso em: 21 de março de 2019.

[13] SILVA, I. G. B. da Adesão/Grau de cumprimento das jovens â vacinação contra o vírus do papiloma humano no Centro de Saúde da Covilhã. 2013. Dissertação (Mestrado) - Curso de Medicina. Universidade da Beira Interior, 2013. Disponível em: https://ubithesis.ubi.pt/handle/10400.6/1460. Acesso em: $18 \mathrm{de}$ março de 2019.

[14] VIDALE, G. Adesão à vacina contra o HPV é baixa. Entenda o porquê. Veja Saúde: Veja. São Paulo, p. 1-4. abr. 2015. Disponível em: Acesso em: 10 de março de 2019.

[15] ROSA, M.I et.al. Papilomavírus humano e neoplasia cervical. Cad. Saúde pública Rio de Janeiro 2009. 